within two months after they graduate," she says. Some have studied industrial ecology and get policy-oriented jobs, whereas others take manufacturing jobs in pharmaceuticals, polymers or food engineering.

Students who

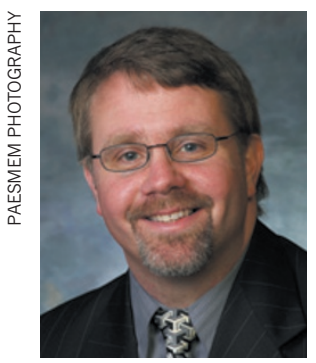
cannot get onto a formal master's or $\mathrm{PhD}$ course that includes green chemistry should "take it upon yourself to get that information anyway", says Warner. One way to do that is through pro"You can't make a career being a green chemist. You do green chemistry in a career." John Warner

grammes aimed at recent graduates, including a week-long summer school run by the ACS in conjunction with its annual conference. Alternatively, meetings with a green-chemistry focus enable networking and an overview of developments in the field. A Gordon Research Conference in Green Chemistry and an associated Gordon Research Seminar will be held in Hong Kong next July, and the University of Nottingham, UK, last month hosted the 6th International Conference on Green and Sustainable Chemistry. Warner Babcock's non-profit education arm, Beyond Benign, also offers resources (www.beyondbenign.org).

Fortunately, green-chemistry courses are becoming more common. Yale University in New Haven, Connecticut, which Muollo turned down in 2005, now has a Center for Green Chemistry and Green Engineering. Founded in 2007 by current director Paul Anastas, who co-wrote the textbook Green Chemistry (Oxford University Press, 2000) with Warner, the centre offers courses on green engineering and sustainable design, product life-cycle assessment, waterresources management and how businesses can become greener.

The field, says Muollo, has grown since 2005. Eventually, she says, green will be integral to chemical manufacturing. "I think green chemistry is going to become chemistry." -

Neil Savage is a freelance writer based in Lowell, Massachusetts.

\section{CORRECTION}

The Turning Point about Jason Weber (Nature 500, 493; 2013) wrongly identified Senator Dick Durbin as a Republican. He is a Democrat.

COLUMN

\title{
Two-body blessing
}

\section{Romantic partnerships between scientists offer plenty of benefits, argues J. T. Neal.}

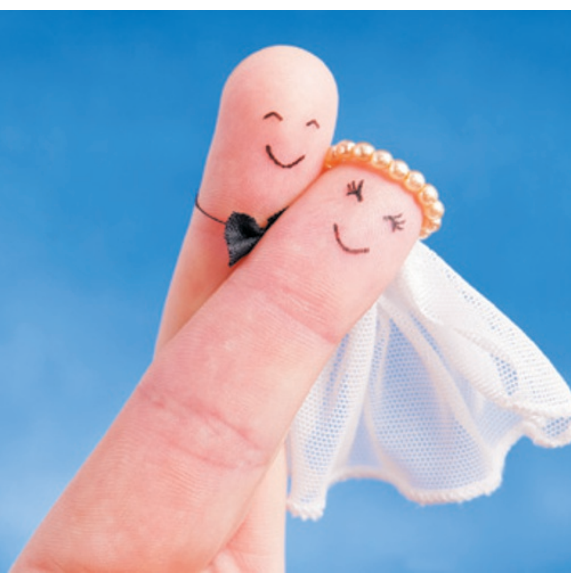

$\mathrm{I}$ am frequently amazed by how many of my fellow scientists are unwilling to pursue romantic relationships with other scientists. No matter how many times I tell them how great it is that my wife is also in science, too many have heard horror stories from a mentor or colleague about spouses forced to find jobs with carnivals, impact-factor-related divorces or children lost to the liberal arts.

"Don't you just talk about work all the time?" they ask. What? No! Sure, our dinner conversations sometimes cover the advantages of stimulated emission depletion over confocal microscopy, the finer points of TAL-effectornuclease design, or whether Reviewer 3 would be more appropriately classified as an Old or a New World monkey (I say New World; you would need a prehensile tail to grasp at that many straws!). But we are just as likely to talk about, you know, the weather. Or that movie the one we are totally going to see next week. Probably. Or that local sports team.

It is true that science can be hard on a relationship. Late-night data-gathering, grant-application deadlines and manuscript revisions can play havoc with domestic bliss. But who is going to understand these challenges better than another researcher? A scientist-partner will accept you stumbling, bleary eyed, into the house in the middle of a week night without accusing you of carousing or philandering (I spilled 70\% ethanol on myself, I swear!). A scientist-partner will sympathize when your undergraduate research assistant kinks the light guide on your tissueculture scope the day before the lab meeting (I'm looking at you, Ben).
A scientist-partner really understands the myriad daily successes and failures that are unique to science, and either too obscure or too unimaginably mundane for the rest of the world to care about. My wife and I drank champagne when her paper was accepted and ate tiny, expensive French food when I got my fellowship. We spent a week in sweatpants when my paper was rejected for the 16 th time, and ate fast food and ice cream when she got scooped. I pack leftovers for her to eat when she gets back from her 1 a.m. experiment. She massages my pipetting arm after 12 straight hours in the tissue-culture hood. It's awesome.

And that is not all. Your scientist-partner can act as a 24-hour sounding board for your next great scientific idea."Hey honey, what do you think about a forward genetic screen in African elephants? No? I guess you're right. That'll never fly in this funding climate."

"But what about the two-body problem?" you ask. "It's hard enough to get one faculty job as it is." Ah, the dreaded two-body problem. It sounds like some kind of development patterning defect. Sure, getting two science jobs in the same time zone can be tricky, but what about all those Egyptologist couples? The two-body problem is far from unique to
"A scientistpartner really understands the myriad daily successes and failures that are unique to science." academia, or to science in particular, because, no matter how you slice it, balancing two careers is hard (see Nature 466, 1144-1145; 2010). We scientists like to imagine that we are exceptional in all things (and we mostly are), but all relationships, scientific or otherwise, require hard work and patience to succeed. Thankfully, scientists have these in spades. (Wine also helps.)

As for my wife and me, I am not sure how it will all shake out when we finish our postdocs and start looking for positions in academia and/or industry. But I know one thing: I wouldn't trade our situation for anything. Not even a full professorship.

J. T. Neal is a postdoctoral fellow in cancer research at the Stanford University School of Medicine in California. 